Kinestetik : Jurnal Ilmiah Pendidikan Jasmani 5 (2) (2021)

Kinestetik : Jurnal Ilmiah Pendidikan Jasmani

https://ejournal.unib.ac.id/index.php/kinestetik/index DOI : 10.33369/jk.v5i2.16953

\title{
ANALYSIS OF VOLLEYBALL EXTRACURRICULARCITY AT STATE JUNIOR HIGH SCHOOLS IN BENGKULU
}

\author{
Defliyanto $^{1}$, Yarmani ${ }^{2}$, Santun Sihombing ${ }^{3}$, Nengsi Kemala Sari ${ }^{4}$ \\ ${ }^{1234}$ Physical Education, Universitas Bengkulu, Bengkulu, Indonesia
}

Article Info

Article History :

Received : June 2021

Revised : June 2021

Accepted : June 2021

Available online : June 2021

Keywords:

Coaching, Extracurricular, Volleyball

\begin{abstract}
This study aims to determine Analysis of volleyball extracurricular development in junior high schools in Bengkulu city. The type of research used is qualitative with the design of this research is a survey approach. The research subjects, namely coaches, trainers and students at the State Junior High Schools in Bengkulu City which were accredited A totaled 15 schools. The object of this research is volleyball extracurricular at State Junior High Schools in Bengkulu City. The data analysis technique in the field uses the Miles and Huberman model in the form of data reduction, data display, and the last one is drawing conclusions/verification. The results of this study indicate that 15 State Junior High Schools (SMP) in Bengkulu City which consist of 15 coaches, 15 coaches, and 15 students regarding the analysis of volleyball extracurricular coaching at State Junior High Schools in Bengkulu City, it is known that the overall results of the coaching extracurricular activities carried out by the coaches were in the very good category $(85.67 \%)$ then the trainers were in the good category $(76.33 \%)$ and the students were in the good category $(75.33 \%)$. In general, it can be concluded that of the 15 State Junior High Schools in Bengkulu City, it is $(79.11 \%)$ in the good category.
\end{abstract}

\footnotetext{
Corresponding address : Jl. Raden Fatah Rt 17 Rw 03 Kota Bengkulu

*Corresponding email : defliyanto@unib.ac.id
} 


\section{INTRODUCTION}

Sport is very beneficial for human life, because sport can improve the health of character building and individuality, high discipline and specificity, and increased achievement can increase the nation's self-esteem (Nopiyanto \& Raibowo, 2019). The basic purpose of sport is for entertainment, physical education, achieving high performance, maintaining the physical condition of the body and improving the quality of human life.

Sport is one of the activities favored by young and old people. Various efforts have been taken well by government agencies, in this case the Ministry of Youth and Sports (Kemenpora) and other sports institutions to conduct sports development in Bengkulu, as a forum for potential talented children in certain sports, junior high schools in Bengkulu. Bengkulu has opened extracurricular activities, one of which is volleyball extracurricular.

Coaching is a factor that plays an important role in the world of sports, especially volleyball, volleyball sports coaching needs to be done as early as possible through talent search and scouts, nurseries, education and sports training based on science and technology effectively and efficiently, because the sport develops or not. Depends on coaching the sport itself. Sports coaching for an athlete cannot be done instantly, but through various processes and stages within a certain period of time.

Volleyball is a sport that is very popular with the wider community. Peak performance volleyball is characterized by the team's search for balance between different actions, complexes or phases of play (Yanti et al., 2021). Volleyball game is one type of game that has the characteristics of movement skills that are not easy to master, so it needs good and systematic training stages so that volleyball playing skills can be mastered well. The basic techniques of volleyball games include lower servicing, servicing top, passing, bottom passing over, smash,and block. In general, this game requires good physical condition, especially agility and coordination in hitting.

Extracurricular activities are learning activities, the time exceeds the scheduled time in planning arrangements such as enrichment activities, improvements related to extracurricular activities, but there is still a lack of full support from every State Junior High School in Bengkulu City in developing volleyball extracurricular activities. Developing extracurricular quality requires the role of teachers as volleyball extracurricular coaches at State Junior High Schools in Bengkulu City with the aim of increasing student talent and increasing student achievement in sports.

Extracurricular coaching consciously has a positive impact, this extracurricular can be used as a forum for students to gain achievement. There are still many extracurricular plans that need to be considered in order to achieve the desired achievement. Therefore, what needs to be considered is that the budget for volleyball extracurricular needs is not optimal. The sports extracurricular training 
program must be systematically structured, meaning that you exercise regularly and continuously, from simple to complex. The lack of maximum sports extracurricular activities at State Junior High Schools in Bengkulu City, therefore the trainers need to be varied in training these students, plus the facilities and infrastructure that are less supportive to cause students to be less interested and enthusiastic in participating in volleyball extracurricular activities.

Based on this, the authors estimate that the less than optimal achievement of volleyball in SMP Negeri in Bengkulu City is due to the lack of structured and directed coaching and training and also the lack of attention from schools and local governments in supporting student achievement at national and international levels because there is no research on analysis of extracurricular development at State Junior High Schools in Bengkulu City. Therefore, it is necessary to evaluate the success of the extracurricular program implemented (Raibowo et al., 2020). Therefore, the authors are interested in conducting research with the title "Analysis of Volleyball Extracurricular Development at State Junior High Schools in Bengkulu City". This research is expected to contribute to or improve the extracurricular development of volleyball at SMP Negeri in Bengkulu City.

\section{METHODS}

type of research is qualitative using descriptive method. The research design used in this study is a survey approach. This research was conducted from April 16 - May 12, 2021. The location of this research was in Bengkulu City State Junior
High School. The subjects of this study were coaches, trainers and students at the State Junior High Schools in Bengkulu City which were accredited A totaling 15 schools. The object of this research is volleyball extracurricular at State Junior High Schools in Bengkulu City. Data collection techniques used were observation, questionnaires (closed questionnaire), and documentation.

The data analysis technique used in the field is the Miles and Huberman model in the form of data reduction, data display, and finally conclusion/verification. The data analysis technique in this study used descriptive analysis techniques. Calculations in the questionnaire used descriptive percentages. How to calculate data analysis to find thefrequency of the relativepercentage. With the following formula (Anas Sudjiono, 2008).

$$
P=\frac{\mathrm{F}}{\mathrm{N}} \times 100 \%
$$

Information:

$\mathrm{P}=$ Percentage sought (Relative Frequency)

$\mathrm{F}=$ Frequency

$\mathrm{N}=$ Number of Respondents

To calculate the percentage with the following formula:

Table Categorization Norms

\begin{tabular}{lcc}
\hline No & Percentage & Category \\
\hline 1 & $81 \%-100 \%$ & Very Good \\
\hline 2 & $61 \%-80 \%$ & Good \\
\hline 3 & $41 \%-60 \%$ & Enough \\
\hline 4 & $21 \%-40 \%$ & Less
\end{tabular}




\begin{tabular}{lll}
\hline 5 & $0 \%-20 \quad$ Very Less
\end{tabular}

\section{RESULTS}

Table 1. Results of the indicator-builder questionnaire in Bengkulu City Public Junior High Schools

\begin{tabular}{|c|c|c|c|}
\hline No & $\begin{array}{c}\text { Indicat } \\
\text { or }\end{array}$ & $\begin{array}{c}\text { Perce } \\
\text { ntage } \\
(\%)\end{array}$ & Category \\
\hline 1 & $\begin{array}{c}\text { Compet } \\
\text { encecoa } \\
\text { ches }\end{array}$ & 78.67 & Both \\
\hline 2 & $\begin{array}{c}\text { Facility } \\
\text { infrastru } \\
\text { cture }\end{array}$ & 91.67 & Very Good \\
\hline 3 & $\begin{array}{c}\text { manage } \\
\text { ment }\end{array}$ & 90.00 & Very Good \\
\hline 4 & $\begin{array}{l}\text { method } \\
\text { of } \\
\text { exercise }\end{array}$ & 83.33 & Very Good \\
\hline 5 & $\begin{array}{c}\text { Achieve } \\
\text { ment }\end{array}$ & 86.67 & Very Good \\
\hline & $\begin{array}{c}\text { Average } \\
- \\
\text { Average }\end{array}$ & 85.67 & Very Good \\
\hline
\end{tabular}

Based Table 1 shows that from the results of the questionnaire supervisor the indicators show the competence of the trainer with the results of $78.67 \%$, facilities and infrastructure $91.67 \%$, Management $90.00 \%$, training methods $88.33 \%$, Achievement $86.67 \%$. With 4 categories "Very Good", and 1 category "Good", while if viewed from the average results showed $85.67 \%$ with the category "Very Good".

Table 2 results. Results of the indicator trainer questionnaire in Bengkulu City Public Junior High Schools

\begin{tabular}{|c|c|c|c|}
\hline No & Indicator & $\begin{array}{c}\text { Percent } \\
\text { age } \\
(\%)\end{array}$ & Category \\
\hline
\end{tabular}

\begin{tabular}{cccc}
\hline 1 & $\begin{array}{c}\text { Competence } \\
\text { of trainers }\end{array}$ & 73.33 & Good \\
\hline 2 & $\begin{array}{c}\text { Facilities } \\
\text { and } \\
\text { infrastructur } \\
\text { e facilities }\end{array}$ & 78.33 & Good \\
\hline 3 & Managemen & & \\
& $\mathrm{t}$ & 83,33 & Very Good \\
\hline 4 & methods & Trainin & Good \\
& & $\mathrm{g} 78,33$ & \\
\hline 5 & Achievemen & 66,67 & Good \\
& $\mathrm{t}$ & 76,33 & Good \\
\hline \multicolumn{4}{c}{ Average } \\
\hline
\end{tabular}

Based on Table 2 shows that from the results of the trainer's questionnaire the indicators show the competence of the trainer with the results of $73.33 \%$, facilities and infrastructure facilities and infrastructure $78.33 \%$, Management $83.33 \%$, training methods $78.33 \%$, Achievement $66.67 \%$. With 4 indicators showing the "Good" category, and 1 indicator showing the "Very Good" category, while if viewed from the average, the results show $76.33 \%$ in the "Good" category.

Table 3 Results of Student Questionnaires at State Junior High Schools in Bengkulu City

\begin{tabular}{cccc}
\hline No & $\begin{array}{c}\text { Indicato } \\
\mathbf{r}\end{array}$ & $\begin{array}{c}\text { Perc } \\
\text { entage } \% \\
\text { ) }\end{array}$ & $\begin{array}{c}\text { Cate } \\
\text { gory }\end{array}$ \\
\hline 1 & $\begin{array}{c}\text { Competence } \\
\text { of trainers }\end{array}$ & $\begin{array}{c}70.67 \text { Trai } \\
\text { ning }\end{array}$ & Good \\
\hline 2 & $\begin{array}{c}\text { Facilities and } \\
\text { infrastructure }\end{array}$ & 76.67 & Good \\
\hline 3 & Management & 78.33 & Good \\
\hline 4 & methods & 81.67 & $\begin{array}{c}\text { Very } \\
\text { good }\end{array}$ \\
\hline 5 & Achievement & 68.89 & Good \\
\hline
\end{tabular}




\begin{tabular}{ccc}
\hline $\begin{array}{c}\text { Average - } \\
\text { Average }\end{array}$ & 75.33 & Good \\
\hline
\end{tabular}

Based on Table 3 shows that from the results of the student questionnaire the indicators show the competence of the trainer with the results of $70.67 \%$, facilities and infrastructure facilities and infrastructure $76.67 \%$, Management $78.33 \%$, training methods $81.67 \%$, Achievement $68.89 \%$. With 1 indicator showing the "Very Good" category, and 4 indicators showing the "Good" category, while if viewed from the average, the results show $75.33 \%$ in the "Good" category.

Table 4. General results of the questionnaire in Public Junior High Schools in Bengkulu City

\begin{tabular}{|c|c|c|c|c|}
\hline No & $\begin{array}{c}\text { Name of } \\
\text { School }\end{array}$ & $\begin{array}{c}\text { Coach } \\
(\%)\end{array}$ & $\begin{array}{c}\text { Train } \\
\text { er } \\
(\%)\end{array}$ & $\begin{array}{l}\text { Studen } \\
\text { ts }(\%)\end{array}$ \\
\hline 1 & SMPN 11 & 90 & 75 & 80 \\
\hline 2 & SMPN 2 & 85 & 75 & 70 \\
\hline 3 & SMPN 14 & 75 & 75 & 70 \\
\hline 4 & SMPN 8 & 95 & 85 & 85 \\
\hline 5 & SMPN 18 & 100 & 80 & 80 \\
\hline 6 & SMPN 6 & 80 & 70 & 70 \\
\hline 7 & SMPN 10 & 95 & 80 & 75 \\
\hline 8 & SMPN 21 & 85 & 80 & 85 \\
\hline 9 & SMPN 16 & 80 & 85 & 75 \\
\hline 10 & SMPN 17 & 80 & 75 & 75 \\
\hline 11 & SMPN 5 & 85 & 75 & 80 \\
\hline 12 & SMPN 1 & 90 & 75 & 75 \\
\hline 13 & SMPN7 & 80 & 70 & 65 \\
\hline 14 & SMPN 15 & 90 & 70 & 75 \\
\hline 15 & SMPN20 & 75 & 75 & 70 \\
\hline \multicolumn{2}{|c|}{ Average } & 85.67 & 76.33 & 75.33 \\
\hline
\end{tabular}

Based on the results Questionnaire data in table 4 It can be concluded that the extracurricular development of volleyball at SMP Negeri Bengkulu City has a very good category. With the results of the percentage of coaches $85.67 \%$, trainers $76.33 \%$, and students $75.33 \%$.

\section{DISCUSSION}

Description of the results of the data above is about "Analysis of extracurricular volleyball coaching at State Junior High Schools in Bengkulu City". Analysis is the process of expressing something scientifically based on certain studies. In this study the data will be discussed based on the results of observations, questionnaires, and documentation. The following is a discussion of the research that has been done.

\section{Observations}

Based on the results of observations that have been made, the analysis of volleyball extracurricular development in Bengkulu City State Junior High Schools that the 15 schools already have good coaches in managing the volleyball extracurricular organization in schools running according to the organizational structure, the coach is said to be good because the coach has run the program according to the structure and have its own strategy, students in each school play a very good role in participating in volleyball extracurricular activities and they can develop their talents. While the facilities and infrastructure in each school are adequate, however, there are several schools in the Bengkulu City State Junior High School 
whose fields are less suitable and the number of balls is minimal, as well as other equipment that is less supportive.

\section{Questionnaire}

Based on the results of the distribution of questionnaires that have been carried out at SMP Negeri in Bengkulu City with the number of subjects 45 people which are divided into 15 coaches, 15 trainers, and 15 students who have filled out the questionnaire distributed by researchers. With the results of the percentage of coaches $(85.67 \%)$ in the very good category, the percentage of trainers $(76.33 \%)$ in the good category, and the percentage of students $(75.33 \%)$ in the good category. These results are supported by the results of previous research conducted by the analysis of the development of futsal extracurricular where the results obtained are $666,66 \%$ developing 6 schools, $33.33 \%$ not developing 3 schools. This result is supported by research conducted by (Rahmadianti, 2019) regarding the analysis of futsal extracurricular development where it is known that 6 schools have developed $66.66 \%$, and 3 schools have not developed $33.33 \%$.

The guiding indicators from the results of the research obtained are described as the data of the results of the research regarding the extracurricular development of volleyball in SMP Negeri in Bengkulu City. Based on the results of the trainer competency questionnaire, the school got data with a percentage $(78.67 \%)$ in good category, facilities and infrastructure indicators with a percentage $(91.67 \%)$ in very good category, management indicators with a percentage
$(90.00 \%)$ in very good category., the indicator of the exercise method with a percentage $(88.33 \%)$ in the very good category, and finally the achievement indicator with a percentage $(86.67 \%)$ in the very good category.

Meanwhile, the trainer indicator from the research results obtained was described as the research data regarding volleyball extracurricular coaching at SMP Negeri in Bengkulu City. Based on the results of the trainer competency questionnaire, the school got data with a percentage $(73.33 \%)$ in good category, indicators for facilities and infrastructure with a percentage $(78.33 \%)$ in good category, management indicators with a percentage $(83.33 \%)$ in very good category, indicator of exercise method with percentage $(78.33 \%)$ in good category, and the last indicator of achievement with percentage $(66.67 \%)$ in good category.

On the student indicators from the results of the research obtained, a description of the research data regarding the extracurricular development of volleyball sports in the State Junior High Schools in Bengkulu City is described. Based on the results of the trainer competency questionnaire, the school got data with a good percentage (70.67\%), facilities and infrastructure indicators with a percentage $(76.67 \%)$ in good category, management indicators with a percentage (78.33\%) in good category, method indicators exercise with a percentage $(81.67 \%)$ in the very good category, and finally the achievement indicator with a percentage $(68.89 \%)$ in the good category. This result is supported by the results of previous research conducted by (Herianto 
et al., 2019) about the analysis of the ability of open spike in volleyball extracurricular male students where the results obtained are in the less and very poor categories as many as 10 students $(33.33 \%)$, which are sufficient and moderate categories as many as 4 students $(13.33 \%)$, which good category as many as 2 students $(6,66 \%)$, and very good category $(0 \%)$.

The results obtained from observations and questionnaires that have been carried out by researchers to coaches, coaches, and students about the analysis of volleyball extracurricular coaching at SMP Negeri in Bengkulu City, in terms of competent competencies about coaches consisting of coach competencies are coaches who have have a coaching certificate and have attended volleyball training, the coach is fully required to master every technique in volleyball games such as serve, passing, smash, and block which aims to provide techniques in volleyball games, and the coach's achievements are the experience gained by the coach to as a guide in providing volleyball game techniques. Competent trainers are one of the most important aspects in achieving optimal performance in the field of sports (Sugihartono et al., 2021).

\section{Documentation}

Based on the results of the documentation conducted at SMP Negeri in Bengkulu City, the facilities and infrastructure in schools can be said to be good, but there are still some schools that do not yet have good facilities and infrastructure, such as nets, balls, cones, and fields.

\section{CONCLUSION}

Based on the results of research and discussions that have been carried out in 15 public junior high schools (SMP) in Bengkulu City consisting of coaches, coaches, and students regarding the analysis of volleyball extracurricular development at State Junior High Schools in Bengkulu City, it is known that the results In general, from the extracurricular coaching carried out, the coaches are in the very good category in the percentage of $85.67 \%$, then the trainers are in the good category in the percentage of $76.33 \%$, and the students are in the good category in the percentage of $75.33 \%$, so the general conclusion is in the good category in the percentage of $79.11 \%$.

\section{REFERENCES}

Anggraini, F. L., Hanurawan, F., \& Hadi, S. (2018). Partisipasi Komite Sekolah Pada Kegiatan Ekstrakurikuler. Jurnal Pendidikan: Teori, Penelitian, Dan Pengembangan, 3(5), 544-551.

Candrawati, Y., \& Ilahi, B. R. (2018). Evaluasi Program Pembinaan Prestasi Olahraga Bola Voli Pada Smk Negeri Di Kota Bengkulu. Kinestetik: Jurnal Ilmiah Pendidikan Jasmani, 2(1), 44-48.

Herianto, H., Yarmani, Y., Sutisyana, A., \& Defliyanto, D. (2019). Analisis Kemampuan Open Spike Pada Siswa Putra Ekstrakurikuler Bola Voli Di 
Smpn 18 Kota Bengkulu. Kinestetik, 2(2), 160-165. https://doi.org/10.33369/jk.v2i2.671 3

Kosasih, A. H. (2017). Pengaruh Pembinaan Dan Disiplin Guru Olahraga Terhadap Pengembangan Ekstrakurikuler Bola Voli. Didaktik: Jurnal Ilmiah Pgsd Stkip Subang, 3(1), 85-95.

Ningsih, Tiwi Gusria Dan Witarsyah. (2020). Manfaat Latihan Variasi Jarak Servis Terhadap Ketepatan Servis Atas Peserta Ekstrakurikuler Bola Voli. 2(2016), 916-927.

Nopiyanto, Y. E., \& Raibowo, S. (2019). Filsafat Pendidikan Jasmani \& Olahraga. Bengkulu: Zara Abadi.

Olahraga, P. K., Keolahragaan, F. I., \& Irsyada, D. M. (2012). Karakteristik Permainan Bolavoli Tim Putera Dan Tim Puteri ( Studi Pada Proliga 2012 Di Gresik ) Dwi Hendro Susanto. 1-7.

Priyanto, J., Hidayah, T., \& Nugroho, P. (2014). Model pembinaan prestasi olahraga voli pantai di Kabupaten Indramayu tahun 2013. Journal of Sport Science and Fitness, 3(1).

Rahadian, R. (2019). Model Pembelajaran Smash Bolavoli Pada Siswa Sekolah Menengah Kejuruan. Jurnal Ilmiah Fakultas Keguruan Dan Ilmu Pendidikan, 5(01), 35. Https://Doi.Org/10.35569/Biormati ka.V5i01.412

Rahmadianti, T. (2019). Analisis Perkembangan Ekstrakurikuler Futsal Ditingkat Smp Negeri Kota Bengkulu. Kinestetik, 3(2), 223229.

Https://Doi.Org/10.33369/Jk.V3i2.
8994

Raibowo, S., \& Nopiyanto, Y. E. (2020).

Evaluasi Pembelajaran Pendidikan

Jasmani Olahraga \& Kesehatan pada SMP Negeri Se-Kabupaten Mukomuko melalui Pendekatan Model Context, Input, Process \& Product (CIPP). Jurnal Pendidikan Kesehatan Rekreasi, 6(2), 146-165.

Saputra, D. I. M., \& Gusniar, G. (2019).

Meningkatkan Hasil Belajar Passing Bawah Bola Voli Melalui Bermain Melempar Bola. Gelanggang Olahraga: Jurnal Pendidikan Jasmani Dan Olahraga (JPJO), 3(1), 64-73.

Https://Doi.Org/10.31539/Jpjo.V3i 1.862

Sudiarto, F. K. (2013). Hubungan Daya Ledak Tungkai, Kekuatan Lengan Dan Kelentukan Pergelangan Tangan Dengan Hasil Back Attack Bola Voli Putra Bahurekso Tahun 2013. Skripsi, Pendidikan Kepelatihan Olahraga, Fakultas Ilmu Keolahragaan, Universitas Negeri Semarang. Https://Lib.Unnes.Ac.Id/17071/

Sugihartono, T., Nopiyanto, Y. E., Raibowo, S., \& Ilahi, B. R. (2021). The relationship between athletes' perceptions of Covid-19 and communication with the psychological skills. Journal Sport Area, 6(2), 182-191. https://doi.org/10.25299/sportarea.2 021.vol6(2).6337

Sugiyono. (2016). Metode Penelitian Kuantitatif Kualitatif Dan R\&D. Alfabeta.

Sugiyono. (2017). Metode Penelitian Kuantitatif, Kualitatif, Dan R\&D. 
PT Alfabeta. Bandung.

Wandi, S. (2013). Pembinaan Prestasi

Ekstrakurikuler Olahraga di SMA

Karangturi Kota Semarang.

ACTIVE: Journal of Physical

Education, Sport, Health and

Recreation, 2(8).

Yanti, F. J., Sugihartono, T., \&

Nopiyanto, Y. E. (2021). Pengaruh

Latihan Depth Jump dan Jump to

Box Terhadap Power Otot Tungkai

Pada Siswa MA Muslim Cendikia

Bengkulu tengah. SPORT

GYMNASTICS: Jurnal Ilmiah

Pendidikan Jasmani, 2(1), 24-33.

Zaenal, A. (2016). Pendidikan

Kepelatihan Olahraga Fakultas Ilmu

Keolahragaan Universitas Negeri

Semarang 2016. 